\title{
Quantum Nature of Winter Depression
}

\author{
Adam Adamski
}

University of Silesia, Katowice Branch Faculty of Ethnology and Educational Science, Cieszyn, ul. Bielska 62, Poland

\begin{abstract}
Depression is a disease that concerns a growing group of people: children, youth, adult and the elderly. Statistics indicate that 5 up to $20 \%$ of the population of the globe suffer from it. Women suffer from this disease four times more often than men. Depression is such a mental state in which the patient has a deep sense of meaninglessness of life and sees the world in the gloomy colors. Such a person is depressed, their mood affects the job, interpersonal relationships, and learning process. They have a feeling of hopelessness, worthlessness, pessimism and sadness. In many cases patients suffering from depression contemplate or attempt suicide. They cannot notice the solution of their problems. Moreover, they cannot imagine their future, if they were stopped in time. For such people only the past and their past failures matter. Time stopped for them.

In addition to endogenous depression, there is also autumn-winter depression, which is a seasonal disease. The first symptoms appear in early autumn. The improvement of the patients' mental health is observed from February whereas the next symptoms of the disease appear spontaneously in March and April. Winter depression is caused by a prolonged night in autumn and winter and this fact results in the prolonged synthesis of melatonin by the pineal gland, which affects the development of depression.
\end{abstract}

Keywords: Psychotherapy, phototherapy winter depression, bioplasm system, melatonin.

\section{BIOELECTRONICAL CONCEPTION OF THE WINTER DEPRESSION}

The current biochemical model fails to provide a definite recognition of both nature of life and human psychological functions. Beside traditional, well known chemical reactions, there arises a new reality pertaining to the bioelectronic model of life. In this model, it is assumed that the biological system exhibits physical properties of biological mass and functions as a quantum construction. Basic organic compounds, such as proteins, nucleic acids or melanin are semiconductors and possess the ability to activate charges without ion participation. Semiconductors are good conventers of chemical, thermal and electromagnetic energy into electric energy, and the other way round. They also possess other features such as increased conduction accompanying an increase in temperature, a significant jump in conduction in the presence of minimal donor or acceptor admixtures, the photoelectric phenomenon, it is an increased conduction under the influence of photons and quantum emission of the electromagnetic wave. A semiconductor can be a quantum generator of electrons and photons [1]. In an alternating electric field proteins, amino acids, DNA, RNA, as well as plant and animal tissues are subjects of electrostriction and become quantum generators of phonons, that is the acoustic wave. This occurs because the structures in

*Address corresponding to this author at the University of Silesia, Katowice Branch Faculty of Ethnology and Educational Science, Cieszyn, ul. Bielska 62, Poland; E-mail: a_adamski@o2.pl question are at the same time piezo- and pyroelectric, which means they possess the capacity of thermal and mechanical polarization [2]. Piezoelectrics convert mechanical energy into electric energy, while pyroelectrics convert thermal energy into electric energy [3].

Acoustic effects may take place not only in piezoelectrics, but also in semiconductors. A semiconductor can manage electrons in their induced state. In such cases, nonradiative recombination transmits the energy to the molecular network in the form of quantum acoustic vibration. The transition from the induced state to the basis state has got thus two possibilities: the generation of photon or generation of phonon. Biological mass is then continually shaken and "quantum-chatty". The task of phonons is to condition the cyclicity of quantum effects. They also rise to the rank of an important factor in the creation of the action of life, as they bind optical, electrical, mechanical and magnetic phenomena with biological mass and directly combine all quantum processes with the movement of mass, the electromagnetic wave becomes again an information centre in cell transmission, and phonons play the role of a factor recording sensations in memory through an electromagnetic field [4].

Life is a result of all the chemical, electrical, magnetic, optical and acoustic events occurring in the living organism, in the system of organic semiconductors, piezo- and pyroelectrics [5]. This means that biological tissues have ample capacity for activating electrons, generating fields and for constant 
or variabile polarization independent of the chemical character and ion transportation. Biological mass can thus be electrically active in non-chemical manner. Therefore life take place not in a chemical or electronic system, but to some extent among these two processes. In a living organism, chemical and electronic reactions have been "sewn up". In this way, "a quantum seam of life" has come into existence as the smallest functional unit in the biological system. The entire "quantum link of life" takes place in the molecular network shaken by acoustic quanta [6].

The idea of the coupling of bioelectronic and biochemical process in the human organism is alien to the classical research on the psychological life. This new approach postulates a holistic account of human being and his environment. The model in referring to psychology is very inspiring, because postulates the reception of information from the environment not only via sense receptors, but also through the entire biological organism mass understood as organic piezoelectrics, pyroelectrics and semiconductors. This means that the organism receives information from the environment not only through receptors, but also beyond the sphere of sensory experience in the typical for semiconductors manner, that is with conversion to electric energy. The biological mass has been utilized by nature to create an electronic device working analogically to technical electronic systems, but in on the basis of organic semiconductors, pioezo- and pyroelectrics. The device is powered by chemical energy of a metabolic origin, by electromagnetic energy received among things by melanin, which combines with the photoelectric effects, as well as by thermal and mechanical energy converted by piezo- and pyroelectrics into electric energy [7]. Modern electronics uses biomolecules, such as DNA, RNA, proteins and pigments as electronic material. Additionally, certain biological structures treats as natural electronic device, for example cellular microtubules, cytoskeleton and neurons as biological microprocessors [8]. whereas enzymes as natural diodes and transistors [9]. Apart from the attempts at using biomaterials, particularly enzymes in the socalled biocomputer biotechnology, they are broadly used in constructing biosensors [10]. Interesting here is Liberman's conception of biomolecular quantum computers which views the nerve cell as a computer [11].

The basic energy source for this device is chemical energy understood as electrons bound and freed in the metabolizing process. Impoverishment of chemical metabolism in man causes a change of electromagnetic fields and waves in the particles of the human organism, as it is in the case of old age. In this period of life the organic semiconductors grow old and their exchange is no longer through - there is a disproportion between catabolism and anabolism in favour of the former and with deficiency of the latter. Along with that, the electronic action becomes less effective. Quantum efficiency decreases and the amount of the semiconductor which water is diminishes and can not be supplemented from the outside.

Dehydration of the organism increases with age and the reserves of melanin decrease as the organism grows older. Melanin has the capacity of binding protons and electrons in two independent stages [12]. Melanin deficiency disturbs that relation whereas an increase of melanin content in the biological system is accompanied by an increased circulation of electrons and hence an increased number of electron inductions, highly enhanced generation of photons by radiative recombinations and generation of quantum-acoustic states, that is phonons, by non-radiative transitions. Delocalised electrons and proto-ns, as well as proton semiconductions in biological membranes where active protons are fundamental centres of energy and information transduction play an important role in the structure and functioning of biosystems [13].

Sławiński (2001) claims that life processes and light are inseparable and internally connected due to their electromagnetic nature. Light plays a significant energetic and regulatory role in living organisms and in the entire ecosystem, for instance in photosynthesis, in the process of seeing, in biological rhythms, etc. Changes in the intensity of photon emission are functionally connected with disturbances of homeostasis and their measurements specify the state of organism vitality and the capacity for environmental adaptation [14].

\section{DESCRIPTION OF THE WINTER DEPRESSION}

Depression is a disorder which causes a sense of helplessness, worthlessness, hopelessness and guilt, triggers suicidal thoughts and is connected with fatigue, the lose of interests, problems with engaging in everyday activities, neglect of hygiene. It is accompanied by fear and psychological anxiety. The sick person experiences a sense of constant tension, is unable to relax, feels panic and hyperkinesias, which manifests itself in not knowing where to put oneself and in the constant need of walking or lying. Depression 
makes normal life and functioning in society difficult or even impossible (is found 2-3 times as often in women as in men [15].

The winter depression is by definition a seasonal disorder. The first symptoms appear in early autumn, to be followed by improvement in the psychological health induced by darkness, low temperature and a low piezoand pyroelectric polarization index with a resultant low electric field.

In summer the day is longer than the night and the ratio of melanin to melatonin in the biological system is regulated by light. In winter, the ratio is regulated by the

\section{BIOLOGICAL SYSTEM}

BIOCHEMICAL MODEL (metabolism)

\section{BIOELECTRONICAL MODEL}

\section{Biological mass as an electronic material}

BIOCHEMICAL PROCESSES (electrons)
-- semiconductor

-- piezoelectric

-- pyroelectric

DNA, RNA)

(proteins, melanins,

\section{BIOELECTRONICAL PROCESSES}

(electrons, photons, phonons)

\section{LIFE}

of patients in February and spontaneous recurrence of symptoms in March and April [16]. The winter depression results from the lengthening of the night in autumn and winter, which in turn causes lengthening of the time of melatonin syntesis by the pineal gland. The antidepressant effect is achieved by shortening the time of melatonin secretion as a result of artificial lengthening of daytime. Illumination treatment inhibits melatonin secretion and induces an increased synthesis of melanin. Decreasing the amount of melatonin in the biological system lowers the intensity of the depression syndrome [17].

\section{THE ACTION OF MELANIN AND MELATONIN IN THE WINTER DEPRESSION}

Ultraviolet radiation type $B$ (UVB) is the strongest inducing factor in melanin synthesis. UVB radiation is received on Earth only when the sun is positioned relative to it at an angle wider than $30^{\circ}$. In the area of lowland Poland, the radiation is not observed between November and February, which is a period of "ultraviolet craving" with a lowered index of melanin synthesis leading to frequent cases of the winter depression. Production of melanin is conditioned by the intensity of light, the temperature and electric field resulting from the polarization of the biological pyroand piezoelectric [18]. Production of melatonin is wind and frost. The speed of the wind in winter is $5-10$ times higher than in specifically, it functions in the brain as a detector of the electromagnetic wave, analogically to rhodopsin, which detects the light wave in the eye. In both cases, the brain provides a psychological correction; in the case of rhodopsin, the brain gives colour vision, and thanks to melanin, recognition of the environ-ment and oneself [4]. This means that melanin is also responsible for the process of visual perception and environmental adaptation. The different psychological states are conditioned by the level of neuromelanin in the brain.

Melanin also posseses the ability to change light into sound. It is feasible to hypothesis that melanin, as a piezoelectric semiconductor, simultaneously assumes the roles of an instrument and a virtuoso playing musical composition written in the colours of light. Melanin-induced sounds in various keys transform into movement and engage the body in a "dance of life". In autumn and winter, when the night is longer than the day, the sound, due to the lack of light, dies out in its key and the body plunges into depression [19].

Melanin also exhibits a selective susceptibility to phonons, which means that cells containing melanin are selectively susceptible to acoustic waves [20]. 
Numerous natural phenomena are evidence of some sounds of certain volume stimulate the psychophysical process [21]. These sounds are used in musical therapy of neuroses, emotional disorders, etc. Owing the selective susceptibility to phonons, melanin selects such sounds, which are the most favourable to the organism. However, there is also a reverse side to the effects of the acoustic wave. Acoustic waves of a certain frequency may contribute to disrupted functioning of enzymes [22]. Melanin regulates this process in a way which helps avoid the effects harmful to the biological system. Research has shown that there is a high enzyme deficiency in the biological membranes of nerve cells of people suffering from depression [23].

The most important feature of melanin is its ability to absorb light and retention, to store and recover energy. It protects against oxidative stress by reactive free radicals: peroxyls, hydroxyls and singlet oxygen quenching of excited states [24].

\section{Melanin Converts the Light into Sound}

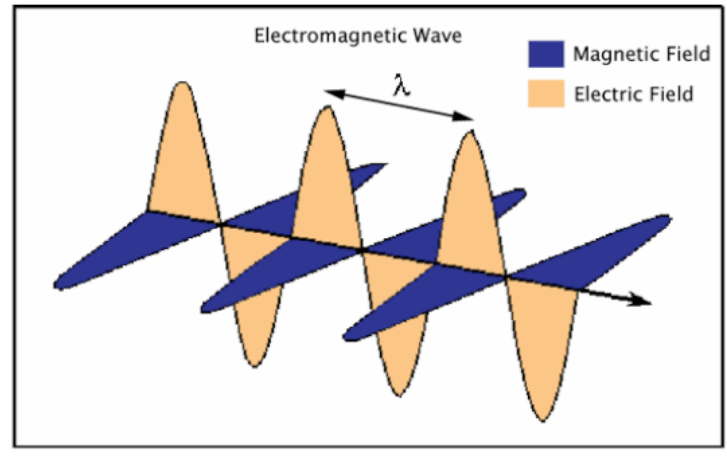

Figure 1: Shows the electromagnetic wave.
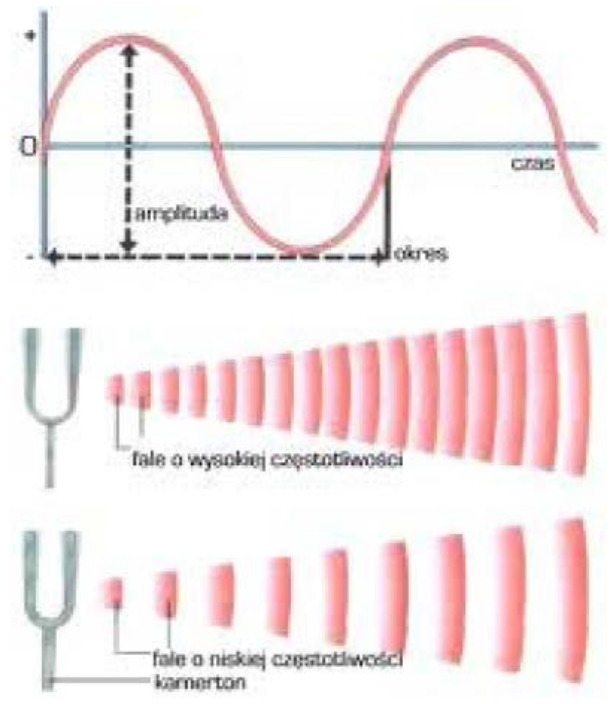

Figure 2: Shows the acoustic wave.
Melanin converts the electromagnetic wave in the acoustic wave, photon in phonon and vice versa: the phonon in the photon $[19,25]$.

Melanin has the ability to direct light, it can accelerate or delay its movement.

\section{Melanin Reverses Light in Torsion Fields}

Photon Converts in the Neutrino

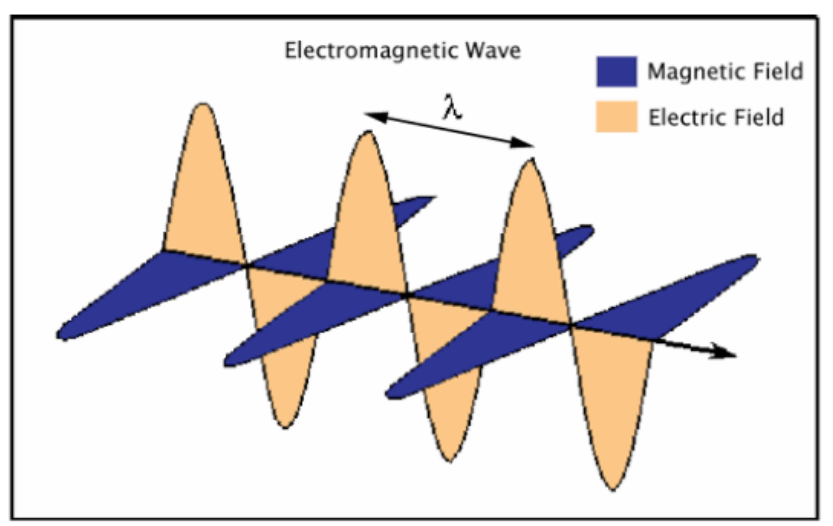

Figure 3: Shows the electromagnetic wave.

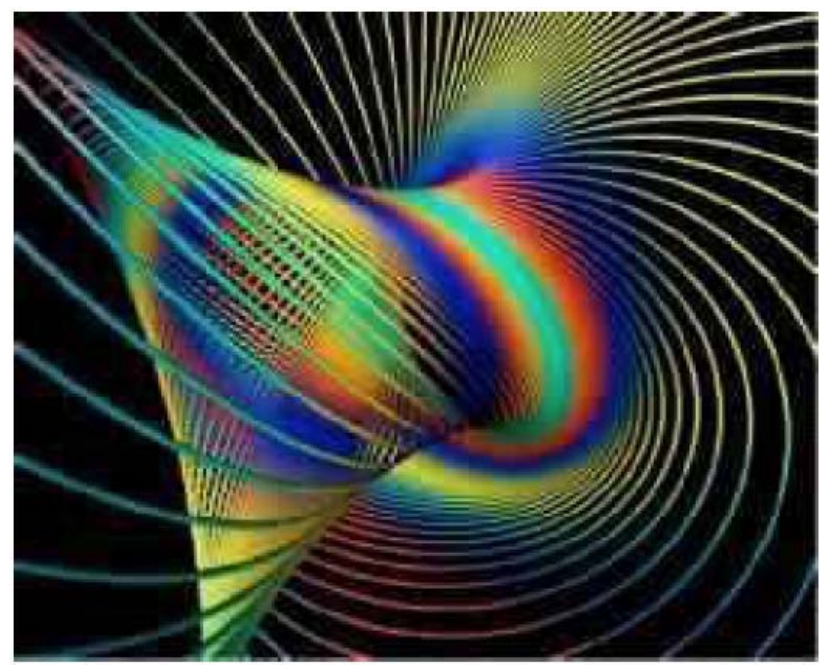

Figure 4: Left and right torsion fields.

Melanin converts the light in the torsion field. Light travels in a vacuum, 300 thousand $\mathrm{km} \mathrm{sec}$ and the torsion field at 10 to $\mathrm{N}$, where $\mathrm{N}$ is the speed of light [26].

Torsion fields are conditioned by spin motion like the mass and spin charge is integrally linked to the particle. Spin is understood as own angular momentum of particles in the system [27]. Each type of particle has an appropriate spin for itself. Spin is a purely quantum concept. In classical mechanics, the particle has zero angular momentum $[28,36]$. 


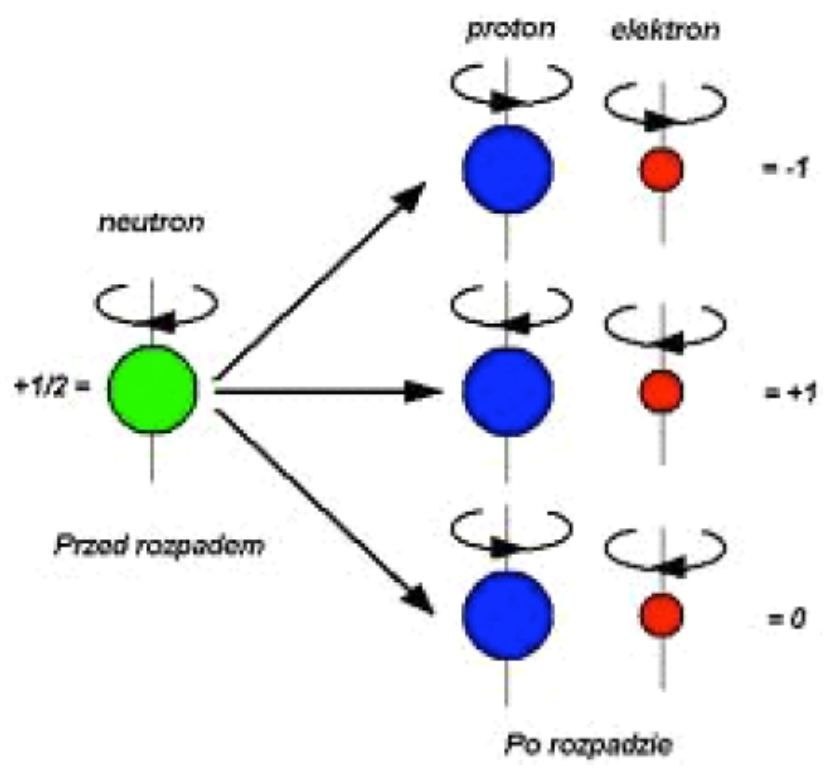

Figure 5: Shows the movement of spin, - to the right or left.

There are left and right torsion fields (depending on the direction of rotation of the spin). Molecular, atomic and nuclear spins determine intensity of the torsion field.According to Shipov every substance has its own characteristic of the torsion field.

\section{The Torsion Fields Produce Solitons}

Transmission of soliton signal takes place not only to biological structures, but also to the psychological and spiritual realm- these are our mental, emotional and conscious states. The soliton waves exhibit incredible resistance to distortion and noise interference. Solitons keep their shape and velocity after a collision with one other. They transmit signals without necessity to move the water environment as a carrier wave. Only the spatial relations, i.e. only geometry of the constellation of water molecules and air without their physical participation, are carried-

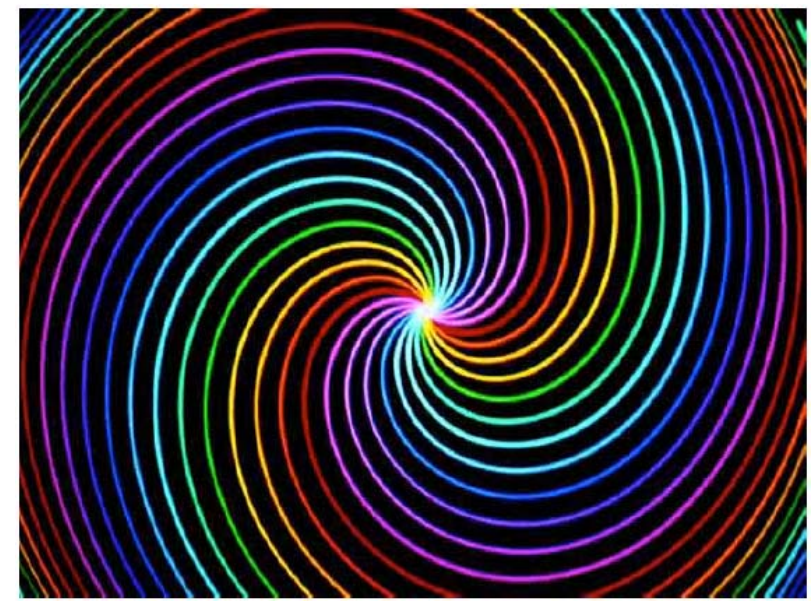

Figure 6: Shows the formation of solitons. environment participates "spiritually" as a structural pattern. Soliton waves have other properties - when two soliton waves approach one another, they "note" and penetrate themselves, but do not overlap; then they diverge in the same order in which they last. They penetrate just temporarily, without losing their identity [29].

Solitons can propagate in the entire universe, without decay; they exist from the beginning of life up to the present. Space is densely filled with a network of solitons, carrying the content and meaning. Brain, and each replication of the genetic code system have transmitter and receiver antennas, which transmit space "directives" [30].

Signal transmission does not have to be made solely under the influence of electro-magnetic and acoustic wave or the electric field [19] - in such a case solitons waves would function as an information carrier, and could have an impact on the energy-informational system of a human being and its behavior [29].

Human biological system is an integrated part of the piezoelectric and pyroelectric elements and semiconductors protein, nucleic acids, DNA, RNA, and melanins. In this circuit there is a biological system in the brain, central nervous system, which can control and coordinate the whole [4].

Control is accomplished by a grid of the following information channels: electron, photon, phonon, soliton, and free radical, and also to bioplasm; any channels of These may be the carrier of information for the biological system in itself, or function as a team in the bioplasm system Interpreted as a set of elementary particles and Mutually interacting fields [31].

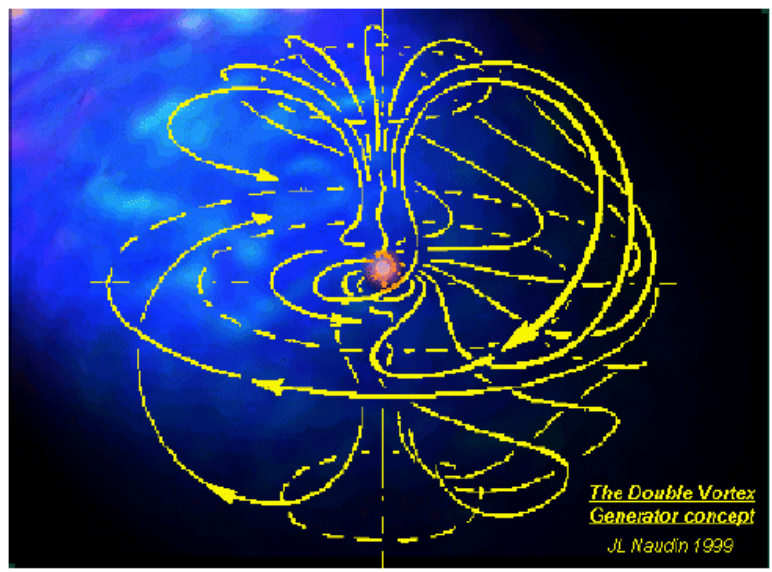

Figure 7: Shows the function bioplasm, which task is to coordinate, integrate, store and manage energy-informational processes in the human biological system. 
Melanins and neuromelanins contain large density of bioplasm and this fact affects the development and degradation of human mental processes. Further understanding of melanins' nature will bring essential contribution to the development of psychology, especially in understanding which factors constitute the essence of the nature of the mental processes. Possession of melanins, neuromelanins and bioplasm in the body forces the science to the new interpretation of the functioning of the sensory perception mechanism and the nature of human mental processes [32].

\section{CONCLUSIONS}

In summary, it is clear that the human psyche develops under the influence of energy factors and information of environment in which a person lives. The biological system plays a role of electronic devices and functions on an electronic material- piezoelectric, pyroelectric paramagnetic and semi conducting. Having this feature it can transmit information to the inside and outside system by electronic means. A major function for the personal development is played by bioplasm:

1. Bioplasm has the capacity to adopt environmental information and to process it at its own information system. The transfer of this information can be realized by means of fields and quanta [7].

2. Bioplasm is the carrier of magnetic, electrical, chemical, mechanical, solitonic, optical, acoustic, gravity information as well as torsion fields [33, 34].

From the point of quantum psychology nature of depression is located in the quantum processes. Lack of exercise in humans, light impacts in the body, reduces the ability of the synthesis of melanin and neuromelanin, which are responsible for the man's mental state. Melanin, neromelanina, proteins, enzymes and nucleic acids bioplasm determine the development of the human body. Loss of biological substances contributes to the loss of bioplasm, which directs the psychic life of man.

Electronic interpretation of living organism has proved to be very inspiring as it takes into account the fact that the information from the surroundings is received not only by sensory receptors and perceptual and motor systems, but also by the entire biological mass of the organism understood as the biological piezoelectrics and semiconductors. The human biological system has a bioelectronic construction and bases its activity on close functional correlation between biochemical and bioelectronic processes. In this new bioelectronic paradigm, there is place for studying man from the perspective of quantum processes. Such an approach brings new knowledge of the processes and psychological functions accompanying personality disorders.

The research carried out by the author using a monochromator has showed that the reception of colors by people in various states of mental health is different. In neuroscience, it is assumed that a person receives the color of the electromagnetic wave between $380-750[\mathrm{~nm}]$, however the range of colour reception changes with the change of the mental state. It means that a person has a different range of perceptual stimuli reception and information from the environment. The author's research has proved that people suffering from depression tend to receive the electromagnetic wave in the range from $620 \mathrm{~nm}$ to 300 $\mathrm{nm}$ that is the ultraviolet range. The state of hyperactivity allows to receive the wave of $450 \mathrm{~nm}-750$ $\mathrm{nm}$; vitiligo $450-590 \mathrm{~nm}$ with the diffused picture and blurred contours, color-blindness - $520-565 \mathrm{~nm}$ and $625 \mathrm{~nm}-740 \mathrm{~nm}$.

Phototherapy, the process of light affecting the body, is an effective treatment for the seasonal depression. Patients are exposed to the illuminator lamps twice a day, in the morning and in the evening (2 hours before the bedtime). These lamps emit light with intensity of 2.5 to 10 thousand lux, without the harmful ultraviolet. The effectiveness of the treatment is 60$80 \%$. Moreover, this treatment improves one's wellbeing. We can also treat depression with music and art therapy. In order to prevent apathy, in time we should take special herbal preparations such as St. John's Wort (Hypericum L.), modify our diet and move much more. Movement activates bioelectronic processes in human biological system, which regulate mental states. Disturbed ratio between melanin and melatonin leads to a mental abnormality. Summer day is longer than the night and it is the light that regulates the proportion of melanin to melatonin in the biological system. In winter, this proportion is regulated by wind and frost. In winter time the winds speed is 5 to10 times higher than in summer and often exceeds $80 \mathrm{~km} /$ hour. Increased wind speeds hit harder in the human body and thus contributes to the growth of biological piezoelectric polarization, which has an impact on the growth of the electric field, whereas this field determines the amount of melanin synthesis. Treatment of depression should 
not be done using pharmacology but using psychotherapy and bioelectronics processes occurring in the human body [35].

\section{REFERENCES}

[1] Gribbin J. W poszukiwaniu SUSY, tr. Bieroń J., publ. Zysk i S-ka, Poznań 2000.

[2] Athenstaedt $\mathrm{H}$. Spontaneous polarization and pyroelectric behavior of organisms. Ferrelectrics 1987; 73: 455-66.

[3] Chełkowski A. Fizyka dielektryków, PWN, Warszawa 1979.

[4] Sedlak W. Wprowadzenie w bioelektronikę, publ. Zakład Narodowy im. Osolińskich, Warszawa-Kraków 1988.

[5] Sedlak W. Homo electronicus. Warszawa: PIW 1980.

[6] Sedlak W. Mała monografia bioelektroniki, publ. Continuo, Radom 2000.

[7] Sedlak W. Bioelektronika 1967-1977. Warszawa: IW PAX 1979.

[8] Hameroff SR, Rasmussen S. Information processing in microtubules: Biomolecular automata and nanocomputers, [w:] Molecular Electronics. Biosensors and Biocomputers, Hong FT, Ed. Plenum-Press, New-York 1989; pp. 243-257.

[9] Cardenas ML. Are the transitory enzyme-compexes found in vitro also transitory in vivo? If so, are they physiologically important. J Theoret Biol 1991; 152(1): 111-13. http://dx.doi.org/10.1016/S0022-5193(05)80522-3

[10] Wnuk M. Istota procesów życiowych w świetle koncepcji elektromagnetycznej życia. Rozprawa habilitacyjna, publ. Katolicki Uniwersytet Lubelski, Lublin 1996.

[11] Liberman EA. Cell molecular computers and biological information as the foundation of nature's laws. BioSystems 1996; 38(2-3): 173-77. http://dx.doi.org/10.1016/0303-2647(95)01588-4

[12] Matuszak Z. Modelowanie komputerowe własności donorowo-akceptorowych melanin, Current Topics In Biophysics, XI Zjazd Polakisego Towarzystwa Biofizycznego, Cieszyn 5-7 wrzesień 2001; p. 80.

[13] Conrad M. Superinformation processing: The feasibility of proton superflow In the living state, [w:] Molecular and Biological Physics of Living Systems, Mishra KR, Ed. Kluwer Accademy Publication, Dordrecht (Boston) London 1990; pp. 159-174.

[14] Sławiński J. Obieg fotonów w układach biologicznych, [w:] Bioelektronika: Materiały VI Sympozjum, Sedlak W, Zon J, Wnuk M, Ed. Katolicki Uniwersytet Lubelski 1990; pp. 189191.

[15] Hauck P. Depresja, tr. Pająk K., publ. Książki i Wiedza, Warszawa 1992

[16] Gamon D, Bragdon A. Co potrafi twój mózg, publ. MEDIUM, Warszawa 2003

[17] Święcicki L. Leczenie depresji zimowej światłem a melatonina, [w:]. Wszechświat 1996; 97(4): 99-100.

[18] Cieszyński T. Pole elektryczne w niektórych poznanych procesach biologicznych, Bioelektronika: Materiały VI
Krajowego Sympozjum. Katolicki Uniwersytet Lubelski, Lublin 20-21 listopada 1987-1990; pp. 89-95.

[19] Adamski A. Melanina, enzymy, melatonina w zdrowiu i chorobie. Rybnik. Wyd. Magnum 2005.

[20] McGuinnes JE, Corry P, Proctor P. Amorphous semiconductor switching in melanins. Science 1974; 1983: 853-55.

[21] Murkowa M. Leczenie chorych z nerwicami i zaburzeniam czynnościowymi, PWN, Warszawa 1972.

[22] Czyżewski A. Sprzężenie ruchu swobodnych nośników ładunku i fal mechanicznych w piezoelektrykach i półprzewodzących strukturach biologicznych, Bioplazma: Materiały II Konferencji na temat bioplazmy, Sedlak W, Zon J, Wnuk M Ed. Katolicki Uniwersytet Lubalski, Lublin 1988; pp. $46-55$.

[23] Mc Ewen B, Norton-Lasley N, Pres J. The End of Stress as we Know it, Washington D. C 24. King R., 2001 Melanin. A key freedom. Chicago. Lushena Books 2002.

[24] King R. Melanin. A key freedom. Chicago. Lushena Books 2001.

[25] McGinness JE, Corry PM, Armour L. Melanin. Bindig drugs and ultrasonic induced cytotoxicity. Pigment Cell Res 1977; 2: 316 .

[26] Shpov Gl, Akimov AE. Torion fields and their experimental manifestations. In Procedings of International conference: NEW IDEAS in Natural Science 1996; available from Alex. V. Frolev, alex@frolov.spb.ru

[27] Shipov CI. Theory of Physical Vacuum",. Moskwa. M., NTCentr 1993.

[28] Akimov AE. Torsion communications of the third millennium. The proceedings of the international conference 'Modern telecommunication technologies. Moscow 1995. Bartlett P. N., Pratt F. E., 1993, Modeling of processes in enzyme electrodes. Biosensors Bioelectronics 1995; 8/9-10: 451-62.

[29] Brizhik L. Soliton generation in molecular chains. Phys Rev B 1993; 48(5): 3142-44.

[30] Brizhik L. Soliton mechanism of charge, energy and information transfer in biosystem ISBN- 981-238-419-7. Wyd. World Scientific Publishing. Co Ptc. Ltd. Singapore 2003.

[31] Sedlak W. Wykłady o bioelektronice, publ. Almapress, Warszawa 1987.

[32] Adamski A, Sławiński J. Consciousness and its unknown face in the light of quantum psychology. Wydawnictwo Napoleon V. Oświęcim 2011.

[33] Sedlak W. Ewolucja bioplazmy. Roczn. Filozof. 23, z. 3 1975; pp. 95-116.

[34] Shipov GI. Theoretical estimation of electrotorsion radiation M.: Preprint N1. MITPF. 1995; 21: 34-42.

[35] Adamski A. Percepcja muzyki, jej wymiar w sztuce psychologii kwantowej. Wyd. Compal. Bielsko- Biała 2008.

[36] Shipov $\mathrm{Cl}$. Unification of interactions In the theory of physical vacuum. Preprint Nr.3. MITPF 1996. 